\title{
Supporting Learning Trajectories for the Development of Number Concept: Digital Games*
}

\section{Sayı Kavramına İliş̧in Öğrenme Yörüngelerinin Desteklenmesi: Dijital Oyunlar}

\author{
Derya CAN ${ }^{* *}$
}

Received: 21 February 2020

Research Article

Accepted: 15 September 2020

ABSTRACT: The aim of this study is to examine the games in ABCya (https://www.abcya.com/) based on the learning trajectories for the development of number concept. To achieve this aim in the study it was examined which $\mathrm{ABC}$ educational game application support the learning trajectory and the development level related to number concept of games. This research was designed in qualitative research methodology based on content analysis method. The ABCya application, which includes a dynamic structure, is suitable for manipulation and includes digital game features with mathematical content which make it appropriate to support the mathematical development of pre-school students. At the same time, the games included in this application support the active participation of children and have motivation-improving features. It is seen that the games mostly support the trajectories of the "recognition of number and subitizing" and "verbal and object counting" for the children aged between 4-6. For the trajectory of the "comparing, ordering and estimating numbers" there are games supporting the perceptual and counting comparison and ordinal numbers, but games supporting the estimation skills are limited. It is very important to introduce the digital platforms that include educational game activities to both teachers and families and to inform them about their contribution to academic development of the children. Digital games should be used as an educational tool by parents and teachers in supporting the development of children and their number sense, especially in the learning trajectory for recognition of number.

Keywords: digital games; learning trajectories; number sense.

ÖZ: Bu araştırmada ABCya (https://www.abcya.com/) uygulamasında yer alan oyunların sayı kavramının gelişimine yönelik öğrenme yörüngelerine göre incelenmesi amaçlanmıştır. Bu amaçla ABCya uygulamasında yer alan oyunlar, sayı kavramının gelişimine ilişkin hangi öğrenme yörüngelerini ve gelişim basamaklarını desteklediği konusunda incelenmiş̧ir. Nitel araştırma yöntemine dayalı olarak gerçekleştirilen bu araştırmada içerik analizi yöntemi kullanılmıştır. ABCya uygulamasının tercih edilmesinin nedeni, bu uygulamanın küçük yaştaki çocukların matematiksel gelişimini desteklemeye yönelik içeriğe sahip ve dinamik, manipüle edilebilen yapıda oyunlar içermesidir. Aynı zamanda bu uygulamada yer alan oyunlar çocukların aktif katılımını desteklemekte ve motivasyonunu artırıcı özellikler taşımaktadır. Oyunlar daha çok 4-6 yaş grubundaki çocuklar için "sayıyı tanılama ve şipşak sayılama" ve "sözel ve nesne sayma" yörüngelerini desteklemektedir. "Karşıllaştırma, sıralama ve tahmin" yörüngesi için algısal ve sayarak karşılaştırma yapma ve sıralı saymaya yönelik oyunlar bulunurken tahmin becerisini desteklemeye yönelik oyunlar daha sınırlıdır. Bu tür dijital ortamlarda yer alan eğitsel oyunların hem öğretmenlere hem de ailelere tanıtılması oldukça önemli olup çocukların akademik gelişimine katkısı hakkında gerekli bilgilendirmeler sağlanmalıdır. Özellikle sayı öğrenme yörüngesindeki gelişim basamaklarının ve sayı duyusunun desteklenmesinde dijital oyunlar aileler ve öğretmenler tarafından eğitsel bir araç olarak kullanılmalıdır.

Anahtar kelimeler: dijital oyunlar; öğrenme yörüngeleri; sayı duyusu.

* This study was presented as an oral presentation at the 2nd International Elementary Education Congress held on 23-27 October 2019.

** Dr., Mehmet Akif Ersoy University, Burdur, Turkey, deryacakmak@mehmetakif.edu.tr, https://orcid.org/00000003-1257-8793

Citation Information

Can, D. (2020). Supporting learning trajectories for the development of number concept: Digital games. Kuramsal Eğitimbilim Dergisi [Journal of Theoretical Educational Science], 13(4), 663-684. 
Children have strong mathematical ideas from an early age and develop and use them to make sense of their daily lives. However, children's opinions and interpretations of certain situations are different from those of adults. For this reason, teachers should interpret what they do and how they think from the point of view of children and act based on their point of view while interacting with the child (Sarama \& Clements, 2009a). Researchers suggests that it is necessary to develop roadmaps for learning processes in order to support students' effective and productive learning, and that teachers should create instructional designs based on these roadmaps when planning the teaching process (Sarama \& Clements, 2009b; Simon, 1995; Wilson, Mojica, \& Confrey, 2013). Sarama and Clements (2009a) developed a theoretical model on these assumptions which is called learning trajectories. This model proposes that mathematical learning is consisted of three components (Sarama \& Clements, 2009b): mathematical aim, developmental progression, and teaching activities. Aims include the great ideas about mathematics and the mathematical field that children should learn. The learning path that children follow to develop skills and understanding about a particular mathematical topic is defined as the developmental progression. It is important for teachers to be informed about this developmental path in that they can interpret what the child is doing and thinking and understand the child's perspective. Being informed about developmental trajectories supports teachers' understanding of student thinking, helps children evaluate their level of understanding and helps teachers to offer instructional activities appropriate to their level. Teaching activities include activity sets that match each level of thinking in the developmental process. These activities enable children to learn new ideas and employ the skills needed to become competent at that level.

\section{Development of the Number Concept}

Number and operation knowledge is the most important field that forms the basis of mathematics learning in early childhood (Clements \& Sarama, 2007; National Council of Teachers of Mathematics [NCTM], 2000). Sarama and Clements (2009a) developed the learning trajectories for the number concept. The goal of these trajectories is to support the development of conceptual understanding about numbers in meaningful contexts. Learning trajectories are defined with some steps called developmental progression and age ranges (Table 1). However, age ranges are identified based on specific studies and may vary in accordance with the experience of students.

Table 1

Learning Trajectories and Development Processes towards the Development of the Concept of Number

\begin{tabular}{llll}
\hline Learning Trajectories & & \\
\hline Age & $\begin{array}{l}\text { Developmental progression } \\
\text { for recognition of number and } \\
\text { subitizing }\end{array}$ & $\begin{array}{l}\text { Developmental progression } \\
\text { for verbal and object } \\
\text { counting }\end{array}$ & $\begin{array}{l}\text { Developmental progression } \\
\text { for comparing, ordering, and } \\
\text { estimating numbers }\end{array}$ \\
\hline $0-1$ & Pre-explicit number & $\begin{array}{l}\text { Pre-counter } \\
\text { Chanter }\end{array}$ & Many-to-one corresponder
\end{tabular}




\section{1-2 Small collection namer}

3

4

5

6

Conceptual subitizer to 20

7

Conceptual subitizing with
place value and skip counting

Conceptual subitizer to five

Conceptual subitizer to 10
Reciter

Reciter (10)

Corresponder

Counter (small numbers)

Counter (10)

Producer (small numbers)

Counter \& producer (10+)

Counter backward from 10

Counter form $\mathrm{N}(\mathrm{N}+1, \mathrm{~N}-1)$

Skip counter by 10 s to 100

Counter to 100

Counter on using patterns

Skip counter

Counter of imagined items

Counter on keeping track

Counter of quantitative

units/Place value

Counter to 200

Number conserver

Counter forward and back
One-to-one corresponder

Object corresponder

Perceptual comparer

Firs-second ordinal counter

Nonverbal comparer of similar items (one-four items)

Nonverbal comparer of dissimilar items

Matching comparer

Counting comparer (same size)

Mental number line to five

Counting comparer (five)

Ordinal counter

Spatial extent estimator-small

Counting comparer (10)

Mental number line to 10

Serial orderer to $6+$

Spatial Extent Estimator

Place Value Comparer

Mental Number Line to 100

Scanning with Intuitive

Quantification Estimator

Mental number line to 1000

Benchmarks Estimator

Composition Estimator

Developmental progression for recognition of number and subitizing starts with innate number sense of children and continues with their ability to designate small-size entities (groups covering 1, 2 and 3 objects). Nearly at the age of 3 children can make a group of objects (range 1-3) without using verbal counting. They can use the perceptual subitizing skills around 4-5 years of age to tell the number of quantities up to 4 and 5 (MacDonald \& Wilkins, 2016). They experience a transition to the conceptual subitizing in the age of 5-6 years and can quickly group the number of quantitites (MacDonald \& Shumway, 2016).

Developmental progression for verbal and object counting starts with random saying of number words and continues with repetition of the number words like singing a song. As their development progresses, children begin to gain cardinal value skills and 
one-to-one correspondence (Gelman \& Gallistel, 1978). They can say the numbers that come before and after a number around 4 years of age and can form groups of objects of small numbers. Around 5 years of age they can comprehend cardinality and count down. In addition, they can make counting by using number patterns. They also begin to comprehend the decimal system and place value (Sarama \& Clements, 2009a).

Developmental progression for comparing, ordering and estimating numbers starts with perceptual and nonverbal comparing of similar items. At the age of 4 children can match and compare the groups of items (for instance, matching three cubes with three points and stating that they are in equal numbers), make comparisons by counting objects from 1 to 5 when objects are about the same size. However, if the physical size of an object in a group is larger, they may think that the number of that group is greater. Around the age of 5 they can compare objects without being affected by the physical size of the objects (Siegler \& Booth, 2004). They can estimate the number magnitudes using the mental number lines, comprehend the concept of place value and compare numbers around 6 years old.

\section{Theoretical Background}

Although what kind of activities can be included in the series of educational activities varies in relation to the age and personal characteristics of children, physical and virtual manipulatives can be used in instructional designs planned to support learning trajectories from early childhood (Sarama \& Clements, 2016).Virtual manipulative is defined as an interactive web-based representation of a dynamic object that provides an opportunity to construct mathematical information (Moyer, Bolyard, \& Spikell, 2002). Virtual manipulatives play an important role in helping children understand multi-faceted ideas such as the use of algorithms from an early age and maintain their physical experience (NCTM, 2000). Virtual manipulatives which are in fact web-based and computer-assisted activities contribute to children's mathematical development from early age. For instance, Moyer-Packenham et al. (2015) analysed how different mathematical applications on tablets lead to a change in the performance and speed of children between the ages of 3-8. It is concluded that the performance of preschool children in seriation and counting activities did not show a significant change, but their speed increased over time. As a result of the research, it was found that different activities addressed to children in different age groups and that some activities had more impact on children's learning performance and speed than others.

Digital games are one of the tools that prevail over other teaching tools as they are fun and interesting for children. These games, unlike traditional methods, involve play-like activities and entertainment in the process and provide a latent learning environment by keeping the learners' motivation high (Bozkurt, 2014). Educational digital games with their strong potential in education that provide advantages for educators and students are very important in terms of children's cognitive development (Oblinger, 2004). Educational digital games are defined as games played with computer systems (video games, computer games and mobile games) that aim to support the learner's academic and psychological development (Samur, 2012). Research shows that educational digital games support children's mathematical development (Manginas \& Nikolantonakis, 2018; Miller, 2018; Pope \& Mangram, 2015; Rogowsky, Terwilliger, Young, \& Kribbs, 2017). For example, in a study by Pope and Mangram (2015) the 
focus was on whether a digital math game developed students' number sense or not. In the study conducted on a sample of the third grade students, the same teacher traditionally taught mathematics both in the experimental and control groups. In the experimental group, the students were allowed to play individual games three times a week for 10 minutes for four weeks. As a result of the activity the experimental group students playing the game called Wuzzit Trouble showed a significant increase in number sense. The study by Manginas and Nikolantonakis (2018) analysed the effects of special education program assisted by digital games on the understanding of students with mental disability in terms of basic mathematical concepts. The content of the games used included topics such as number identification, concept of place value, number comparison and mental computation. Four students aged eleven participated in the study, and two of them were placed in the experimental group and the remaining two in the control group. It was found that the students in the experimental group performed better in mathematical concepts and subjects than the students in the control group. Therefore, it can be argued that online digital games have positive effects on students with low levels of mental disability in understanding basic mathematical concepts. In the study conducted by Miller (2018), the effect of digital mathematical activities used in game-based learning environment on the number sense development of kindergarten children was examined. As a result of the research, it was observed that although there is a small positive difference in the numeracy skills of the experimental group students in terms of success, it increased the cooperation among the students. Rogowsky et al. (2017) designed a computer-assisted instruction to improve the literacy and numeracy skills of 47 children aged between 3,5 and 5,5. Virtual characters were included in this design, and the interaction of children was made possible in the design. Both experimental and computer-assisted group received 11-hour education per week, and the experimental group also received daily ten minutes individualized interactive education. The findings of the study showed that the literacy (e.g., letter-word identification, phonological awareness, etc.) and numeracy (e.g., counting, number recognition, comparisons, etc.) skills of the experimental group significantly increased.

\section{Aim and Significance of the Study}

Research shows that both virtual manipulatives and educational digital games positively support students' mathematical development (Manginas \& Nikolantonakis, 2018; Miller, 2018; Moyer-Packenham et al., 2015; Pope \& Mangram, 2015; Rogowsky et al., 2017). However, in this process, it is very important that teachers should identify the educational games and virtual manipulatives to be used in the teaching process based on the objectives of the teaching process. It is important for teachers to know the learning trajectories in terms of supporting the child's transition from one level to another in the mathematical developmental process. With digital games tailored to learning trajectories, teachers can have the opportunity to identify games that fit both the curriculum and the level of development of each child. Therefore, it is very important to guide teachers in showing how educational digital games support teaching programs. The aim of this study is to examine the games in ABCya (https://www.abcya.com) based on the learning trajectories for the development of number concept. To achieve this aim in the study it was examined which ABC educational game application support the learning trajectory and the developmental level related to number concept of games. It is thought that the results will guide 
educators and families in using digital games to support the transition of children from their current level of development to a higher level.

\section{Research Questions}

How do pre-K and Kindergarten math games covered in ABCya support learning trajectories for the development of the number concept?

More specifically, how do these games in ABCya,

(1) Support the developmental steps concerning the learning trajectory of the "recognition of number and subitizing"?

(2) Support the developmental steps concerning the learning trajectory of the "verbal and object counting"?

(3) Support the developmental steps concerning the learning trajectory of the "comparing, ordering, \& estimating numbers"?

\section{Method}

\section{Research Design}

This research was designed in qualitative research methodology based on content analysis method. Content analysis is a research method that provides a systematic and objective means to make valid inferences from verbal, visual, or written data in order to describe and quantify specific phenomena (Downe-Wambolt, 1992, p. 314).

\section{Sampling}

The materials reviewed in the study are thirteen digital games in the ABCya activity which are designed to support the mathematical development of pre-school children. When selecting a computer game with mathematics content, the game should include features such as how the game develops the mathematical concept, the nature of the mathematical concept, the appropriateness of the children's characteristics in regard to the games, developing a competitive spirit among children, increasing motivation of children and ensuring the active participation of children (Jovanova-Mitkovska, 2018). In addition, an interactive, web-based visual representation of a dynamic object that presents opportunities for constructing mathematical knowledge (Moyer et al., 2002, p. 373). The ABCya application, which includes a dynamic structure, is suitable for manipulation and includes digital game features with mathematical content which make it appropriate to support the mathematical development of pre-school students (Jovanova-Mitkovska, 2018; Ortiz, 2017). In this context, it was decided to examine the 13 games in the $\mathrm{ABC}$ application which were found to support the development of the concept of number. The materials to be analysed in the study were formed by using the convenient sampling method, one of the purposeful sampling methods. In the purposeful sampling method, the elements are not randomly selected from the study universe, but because of their particular characteristics and/or according to the researcher's own decision/common sense (Böke, 2009, p. 125). There are 400 fun and educational games in the ABCya application that target children from preschool to 6th grade. The games are divided into subject areas and sub-subject areas based on the grade level. The games, which are determined as data sources, consist of 13 games that 
cover the sub-subject areas in mathematics. While determining 13 games, the games that are stated to support the counting skills for pre-school period were selected within the framework of Common Core Standarts. The matching between achievements and games was made by ABCya application. However, since Common Core Standarts are unique to the USA, how games support the developmental stages of mathematical thinking in children was examined depending on the learning trajectories.

\section{Data Analysis}

In order to examine which digital games support which of the learning trajectories for the development in the concept of number the developmental steps developed by Sarama and Clements (2009a) were employed. These developmental steps are about three learning trajectories: recognition of number and subitizing, verbal and object counting, comparing, ordering, and estimating numbers. Before the analysis the definitions of the developmental stages under each learning trajectory were examined. In addition, through the web-based tool developed by the authors (https://www.learningtrajectories.org/) the examples of the definitions of learning trajectories that reflect children's thinking processes were reviewed through videos. The descriptions of learning trajectories and video samples were shared with an expert in preschool education. In order to ensure coder reliability, the preschool expert also analysed which digital games support which of the learning trajectories. A consensus was reached between the expert and the author about the learning trajectories that each digital game is thought to support. For example, a game called Counting Fish supports the counting skills of children, but it can also improve their subitizing skills when used appropriately. The game was defined by the author as one supporting both trajectories, and was defined by the expert as one supporting the counting trajectory. However, after discussing it they both concluded that the Counting Fish game could develop both counting and subitizing skills of children. In order to ensure the external reliability of the research the findings obtained were presented to the opinions of two experts in the field of preschool education and mathematics education, and an agreement was reached.

Below are the games and their brief descriptions included in the study, learning trajectories and development steps that can be developed through games:

\section{Digital Math Games for Kindergarten (https://www.abcya.com)}

1. Counting Fish. Recognition of number and subitizing: Perceptual subitizer to 4, perceptual subitizer to 5, conceptual subitizer to 5, conceptual subitizer to 10 , conceptual subitizer to 20 , conceptual subitizing with place value and skip counting

Verbal and object counting: counter (10), counter \& producer (10+)

In this game, children are asked to determine the number of floating fish and mark the number representing the fish among three options. There are three steps: at the first step there are 1-5 floating fish; at the second step there are 5-9 floating fish and at the third step there are 10-20 floating fish (Figures 1a-1b-1c). When the wrong option is selected for the number of fish in the game, there is a warning about the number of fish which is more or less than the correct number of fish. This situation is supportive in terms of the comparison between the numbers of redundancy-multiplicity.

The game, which starts with a smaller number of fish first, supports the ability to 
perform quick snapshots in multiples up to 4 and 5. In later stages, more fish (approximately 10-20) are displayed on the screen. The fact that children form subgroups to determine the total number of multiplicity is a feature supporting the conceptual subitizing skills. In addition, the way fish appear on the screen and their positioning can contribute to the development of conceptual subitizing skills. This game also supports the counter (10+) stage of counting development. At this stage, children can accurately count over 10 objects (usually up to 30) and have comprehended the cardinality. They can follow the counted and non-counted objects even if they are in different order. The ability of children to recognize the counted and non-counted fish while counting the fish and to say how many fish are in total (cardinality) supports the development of the counting learning trajectory.

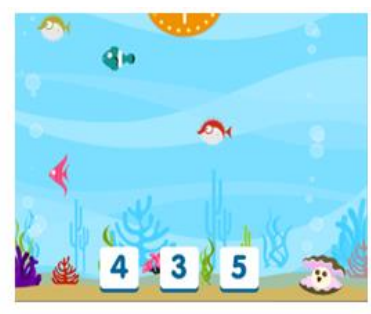

Figure 1a

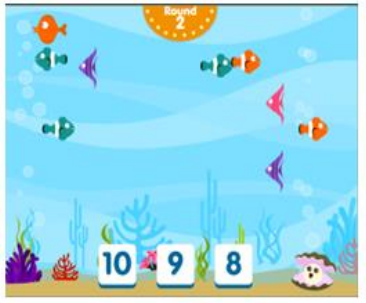

Figure $1 b$

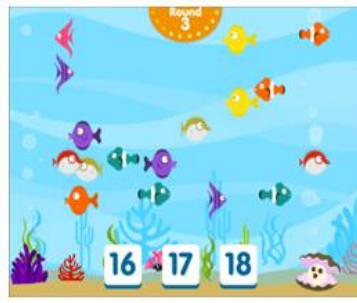

Figure 1c

2. Birthday Candle Count. Verbal and object counting: corresponder, counter small numbers, counter (10)

In this game, children are asked to determine how old a child is by counting the candles (ranging from 1-10) on the cake (Figure 2a). When a candle is clicked it is lit and the ordinal numbers are verbalized (Figure 2b). Following the candles are counted, the child is asked to select the number indicating how old he or she is (Figure 2c). This game, which involves exercises on counting, also supports the principles of matching and cardinal value.

Children who are in the reciter stage can do verbal counting with at least 5 number words. When counting with objects, they can count again or skip without counting as they cannot keep the objects they have in mind. They can mix the places of numbers in the series of numbers above 5. In the next stage they can make up to 10 verbal counts, but they can also make mistakes such as skipping without counting objects or counting twice. This is a game that allows children to attribute a number word to each object. Therefore, it prepares children for the transition to the corresponder stage of the learning trajectories. Because in the Corresponder stage, children are expected to make exact matches between numbers and objects.

The game not only supports the counting by assigning a number word to the candles on the cake, but also requires that children should tell the number of candles on the cake. Because the age of the child for whom the cake was prepared is asked. This feature of the game plays an important role in helping children to move to the counter stage and to make practices. In the Counter (small numbers) stage, children correctly count at least 5 objects arranged linearly and answer the question "How many?" starting from the last number word he said. At the Counter 10 step children can count 10 objects in different sequences. Therefore, by counting the candles on the cake and telling how many candles are there (cardinality) this game supports the children's ability to count 10 
objects in different sequences (counter 10).

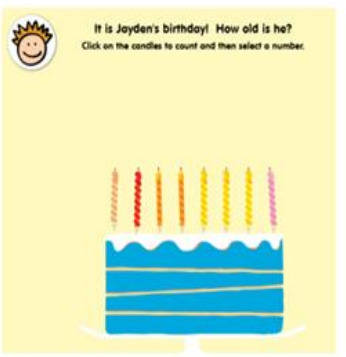

Figure 2a

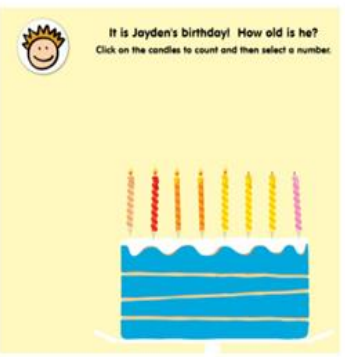

Figure $2 b$

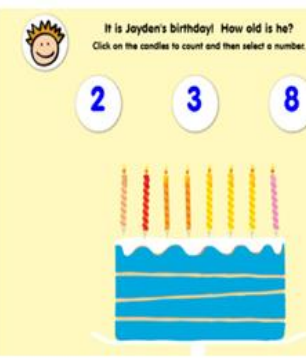

Figure 2c

3. Fuzz Bugs-Counting, Sorting, \& Comparing. Recognition of number and subitizing: perceptual subitizer to 4 , perceptual subitizer to 5, conceptual subitizer to 5 , conceptual subitizer to 10

Verbal and object counting: corresponder, counter (small numbers), counter (10)

Comparing, ordering, \& estimating numbers: perceptual comparer, counting compare (same size), counting comparer (5), counting comparer (10)

As the name implies in the game children are expected to classify, count and compare. They are required to classify the mixed Fuzz Bugs by color, count how many from each color (limited to numbers up to 10), and determine the minimum and maximum number of colors. At the end of the game, children are asked to create their own fuzz bugs in the colors they want. When counting the fuzz bugs accumulated in the jars, the fuzz bug touched comes out and this fuzz bug is given a number word. In this respect, the game supports the skills of one-to-one correspondence and counting (Figure $3 b)$. In addition, the child can decide what the numbers are by subitizing. Therefore, the game also supports the perceptual and conceptual subitizing skills of children (Figure 3c). After the counting process is completed, children are asked to identify the group with the minimum and maximum number of fuzz bugs. This feature of the game supports children's ability to compare through counting something.

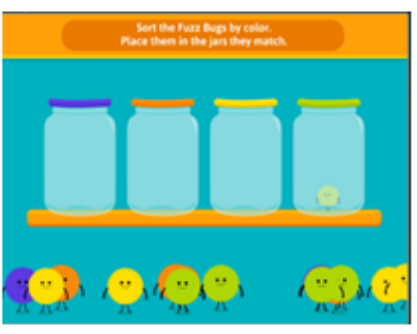

Figure $3 \mathrm{a}$

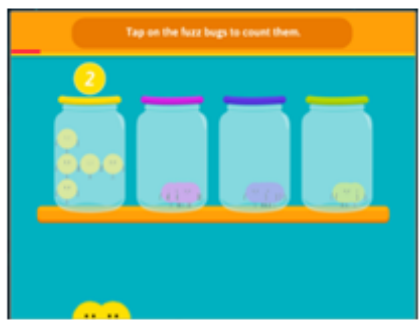

Figure $3 b$

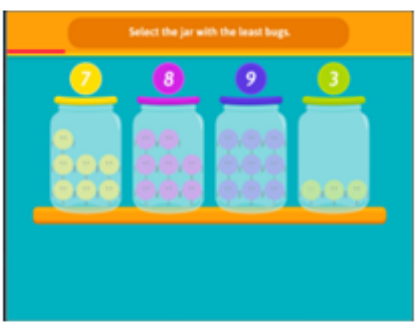

Figure 3c

4. Monster Mansion-Number Match. Recognition of number and subitizing: perceptual subitizer to 4 , perceptual subitizer to 5 , conceptual subitizer to 5 , conceptual subitizer to 10

Verbal and object counting: corresponder, counter (small numbers), counter (10) Comparing, ordering, \& estimating numbers: counting comparer (same size)

In this game, children are asked to match quantities or objects with symbols. In the quantitative matching section, children are expected to match the same pair in 
quantity (Figure 4a). The same format is also available in the form of a memory game. In the memory game, the windows remain closed and the children are expected to remember the number of quantities they have opened. In the formats of the game given in Figures $4 \mathrm{a}$ and $4 \mathrm{~b}$ when children click on the windows, the number of quantities is verbalized. This feature of the game may prevent the child from developing a selfcounting strategy. Therefore, after playing the game in this format, the child should be directed to the matching pairs to decide himself to develop his own counting strategies. In Figures $4 c$ and $4 d$ there are examples about the matching of quantities with symbols in the game. In this section, children are asked to identify and match the number corresponding to the multiplicity. With the aforementioned characteristics of the game, children's perceptual and conceptual subitizing, one-to-one correspondence, cardinal value and comparison skills can be supported.

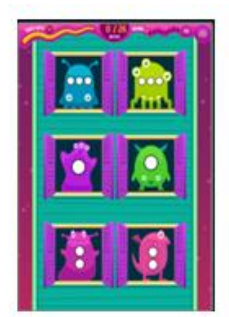

Figure 4a

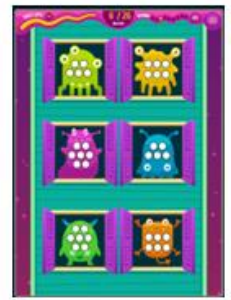

Figure $4 \mathrm{~b}$

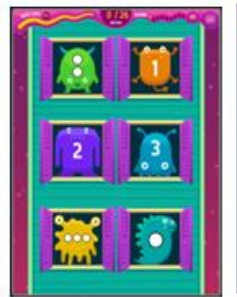

Figure 4c

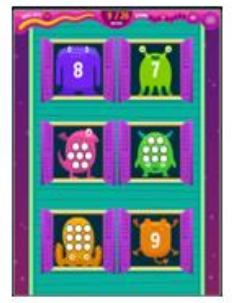

Figure 4d

5. Adventure Man and the Counting Quest. Verbal and object counting: counter from N, skip counter, skip counter by 10 s to 100

Adventure Man game, which jumps through the valleys and swamps to reach the hidden treasure, supports the development of the child's rhythmic counting skills. Children choose a number from 1 to 10 and then, count the numbers in a rhythmic fashion. The number to be chosen varies based on difficulty level in the game. For example, when the child starts from an easy level, he can perform rhythmic counting with single-digit numbers, but if he starts from more difficult stages rhythmic counting is done with two-digit or three-digit numbers. This game supports learning trajectories of rhythmic counting in verbal and object counting.

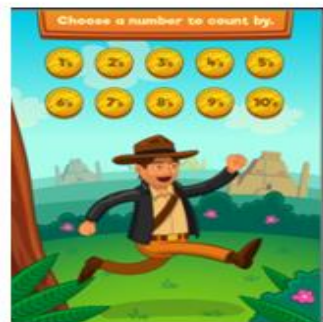

Figure 5a

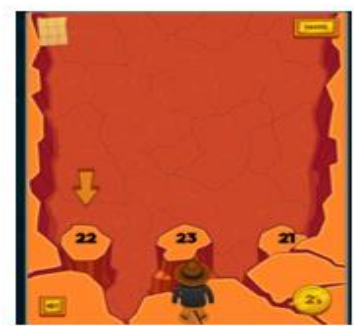

Figure $5 b$

6. Base Ten Bingo. Recognition of number and subitizing: perceptual subitizer to 4 , perceptual subitizer to 5 , conceptual subitizer to 5, conceptual subitizer to 10 , conceptual subitizing with place value and skip counting, conceptual subitizing with place value and multiplication. 
Verbal and object counting: corresponder, counter (small numbers), skip counter by 10 s to 100 , counter of quantitative units/place value.

The Base Ten Bingo game provides an opportunity for children to understand the concept of place value by using virtual manipulatives and to improve arithmetic processing skills. Once the children select the place value and grid you want (Figure 1a), they count the ones, tens, hundreds or thousands groups given on the right side and mark the proper number given in the left side (Figure 6b and Figure 6c). It is aimed to perform BINGO with the numbers coming together up or down. Determining how many unions supports children's perceptual subitizing in multiplicities up to 4 and 5, and conceptual subitizing in multiplicities up to 5 and 10. They can perform conceptual subitizing by using higher level skills such as skip counting, place value, multiplication thinking at the stage where decimal blocks are selected. It is also a game that supports developmental processes such as one-to-one correspondence, cardinal value, skip counting, grouping, digit value, and counting learning trajectories.

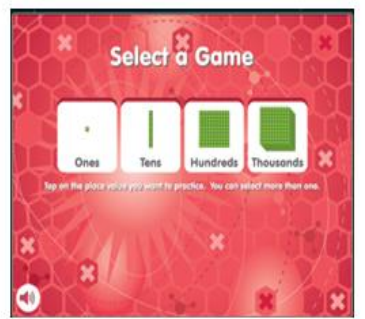

Figure 6a

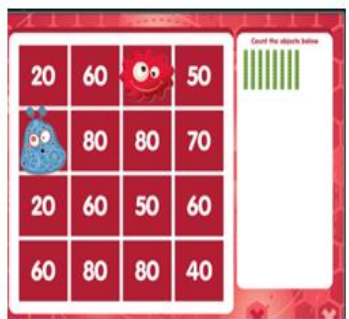

Figure $6 b$

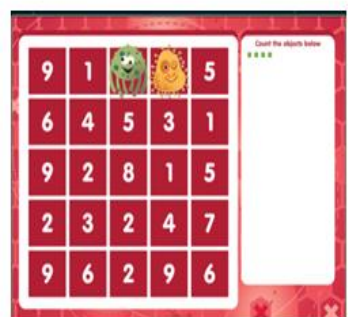

Figure 6c

7. Base Ten Fun. Recognition of number and subitizing: maker of small collection, perceptual subitizer to 4 and 5, conceptual subitizer to 5, 10, 20, conceptual subitizing with place value and skip counting, conceptual subitizing with place value and multiplication

Verbal and object counting: corresponder, counter (small numbers), producer (small numbers), counter \& producer (10+), skip counter by 10 s to 100 , counter on using patterns, counter of quantitative units/place value.

Base Ten Fun game has parallel features with Base Ten Number game. However, this game has been prepared by using snake image instead of ten base blocks and presented in 3 different modes. These three modes are as follows: read \& make, listen $\&$ make, count $\&$ write. In the mode of read $\&$ make (Figure $7 \mathrm{a}$ ) children have the chance to choose one, ten and hundred materials. Therefore, children can be given an opportunity to work gradually based on their level of development. For example, when the ones mode is selected, the image shown in Figure $7 \mathrm{a}$ is displayed and the child is asked to generate the number indicated on the screen. Children's attempt to reach the number by swiping these numbers on the right side of the screen, while the number line at the bottom of the screen progresses to the number of units added. The same process continues in the selection of the groups of tens and hundreds. In the mode of listen $\&$ make (Figure $7 b$ ) the number is verbalized instead of written on the screen. The child is asked to model the number with virtual manipulatives and at the same the unit progress as many as the numbers created in the number line. In the mode of count \& write modunda (Figure 7c) on the right side of the screen, the groups of ones, tens and 
hundreds are given and the child is asked to form the number of representations. This game supports many skills such as forming a specified number of group of objects, perceptual and conceptual subitizing, developing the concept of place value and multiplicative thinking through conceptual subitizing, counting, cardinal value, skip counting and exploiting number patterns. In addition, with the progression of the number of units in the number line, the child has an opportunity to practice the relative size, location, proximity and distance of the numbers. This is a feature that supports the development of number sense.

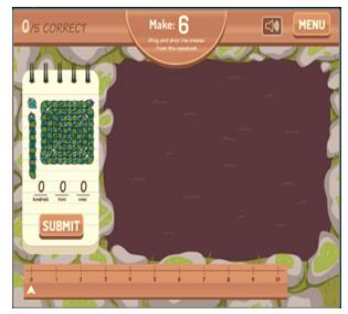

Figure 7a. read \& make

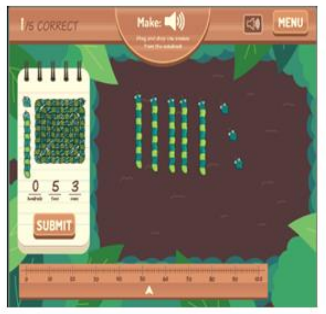

Figure 7b. listen \& make

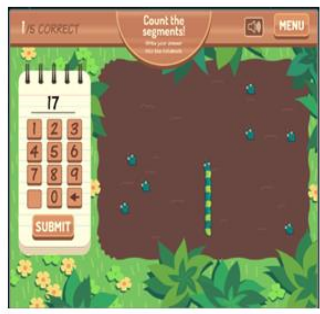

Figure 7c. count \& write

8. Blast off with Numerical Order. Verbal and object counting: counter from $\mathrm{N}$, skip counter by 10 s to 100 , skip counter

Comparing, ordering, \& estimating numbers: ordinal counter

In this game, children are asked to form a series of numbers given in mixed form by performing skip counting. Children are expected to select the appropriate number for their level (Figure 8a) and perform skip counting. (Figure 8b and Figure 8c). The formation of a series of numbers supports the skills related to the ordinal value and also, strengthens their perception concerning the relative size, location, proximity and distance to other numbers.

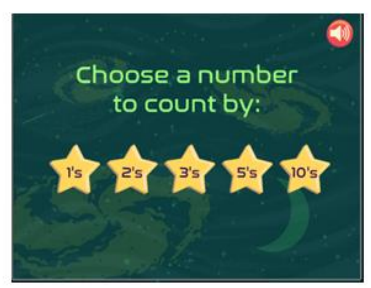

Figure 8a

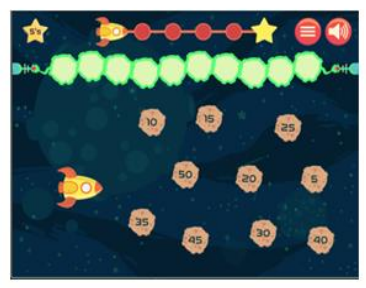

Figure $8 \mathrm{~b}$

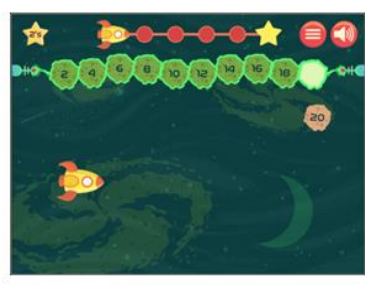

Figure $8 \mathrm{c}$

9. Comparing Number Values. Recognition of number and subitizing: perceptual subitizer to 4 and 5, conceptual subitizer to 5, 10

Verbal and object counting: counter(small numbers)

Comparing, ordering, \& estimating numbers: perceptual comparer, nonverbal comparer of dissimilar items, counting comparer(same size)

In this game, children are shown two groups of dots, and they are asked to compare the number of dots with large, small and equal signs (Figure 1a and Figure 1b). Children can determine and compare the number of dots, as well as perform perceptual comparing. This game supports the development of children's subitizing, counting and comparison skills. 


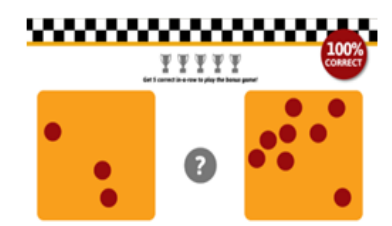

$<\theta \ominus$

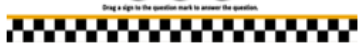

Figure 9a

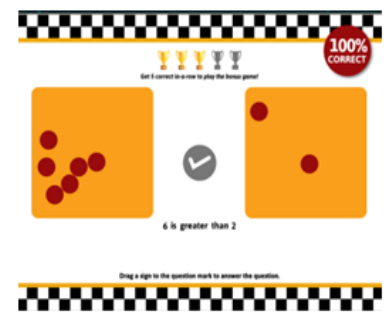

Figure 9b

10. How Many Marbles. Comparing, ordering, \& estimating numbers: scanning with intuitive quantification estimator, benchmarks estimator

In this game, children are asked to estimate the number of marbles in a rotating jar (Figure 10a and Figure 10b). Children are given feedback about their estimations. Children can estimate the number of marbles by considering how many marbles the bottom of the jar can take, and how many layers the jar has.

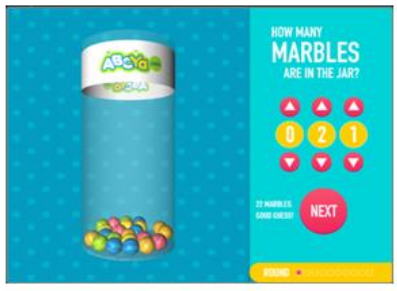

Figure 10a

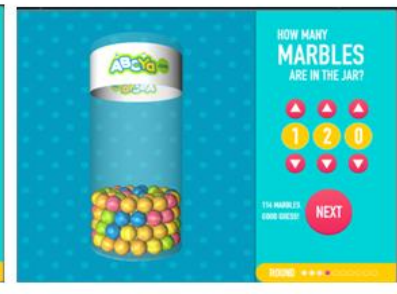

Figure 10b

11. Molly's More or Less Quest. Recognition of number and subitizing: perceptual subitizer to 4and 5, conceptual subitizer to 5 and 10

Verbal and object counting: counter (small numbers)

Comparing, ordering, \& estimating numbers: perceptual comparer, nonverbal comparer of similar items, counting comparer

In this game children are asked to compare the number of living beings and objects that a horse named Molly saw while she was walking. For instance, if she sees three birds on a branch and five birds on the grounds they are asked to answer some questions such as is "The number of birds on the branch smaller than those on the ground?". Children may make comparisons through counting or they may perform perceptual comparing. The game allows children to count objects individually or to perform perceptual and conceptual subitizing. They can also do nonverbal comparison without counting the small number of object groups.

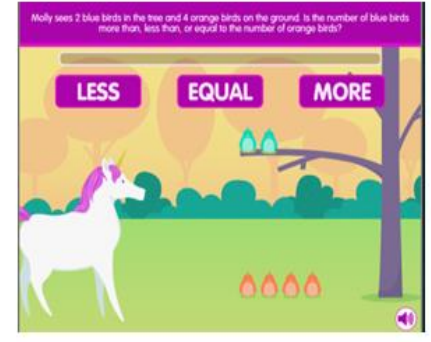

Figure 11a

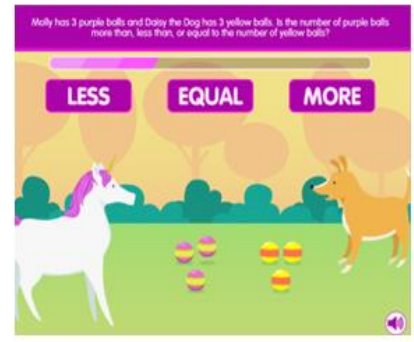

Figure 11b 
12. Number Buble-Count to Ten. Verbal and object counting: corresponder

Comparing, ordering, \& estimating numbers: ordinal counter

In this game, the chests lie on the floor in sequence and the numbers pass through the bubbles in the air. Some of the chests have numbers. It is expected that the children will explode the bubbles into the appropriate chest, taking into account the sequence of numbers. This game improves children's ability to match chests one-to-one with numbers and ordinal value because it requires sequencing according to the sequence of numbers.

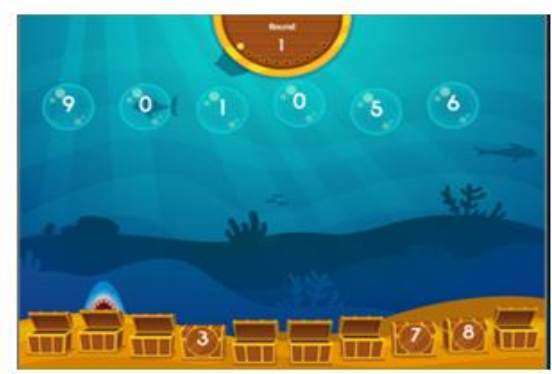

Figure 12a

13. Number Bubble-Skip Counting. Verbal and object counting: counter to 100 , skip counter by 10 s to 100 , skip counter

This game improves children's skip counting skills. At the beginning of the game, children are asked to decide how they want to count in a rhythmic fashion. Numbers are placed in some of the ordered chests according to the selected rhythmic number sequence. In addition, the numbers move in the bubbles in the air in accordance with the selected rhythmic number sequence. It is expected that the children will explode the number of bubbles into the appropriate chest, taking into account the rhythmic sequence. The game improves the ability of skip counting at intervals that children choose based on their level.

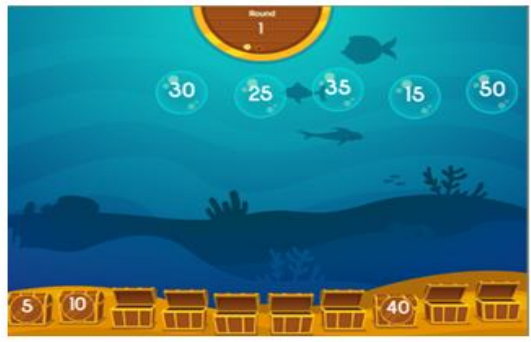

Figure 13a

\section{Results}

Within the framework of the learning trajectories determined for the development of the number concept, 13 games which are included in the educational game application called ABCya and which support the development of the number concept are introduced above. In addition, it is stated which game can support which development level of learning trajectories. Table 2 summarizes learning trajectories and games that support their development. 
Table 2

Digital Math Games Supporting Learning Trajectories

\begin{tabular}{|c|c|c|}
\hline Age & $\begin{array}{l}\text { Developmental progression for recognition of number and } \\
\text { subitizing }\end{array}$ & Games \\
\hline $0-1$ & Pre-explicit number & - \\
\hline $1-2$ & Small collection namer & - \\
\hline 3 & Maker of small collection & 7 \\
\hline 4 & Perceptual subitizer to four & $1,3,4,6,7,9,11$ \\
\hline 5 & Perceptual subitizer to five & $1,3,4,6,7,9,11$ \\
\hline 5 & Conceptual subitizer to five & $1,3,4,6,7,9,11$ \\
\hline 5 & Conceptual subitizer to 10 & $1,3,4,6,7,9,11$ \\
\hline 6 & Conceptual subitizer to 20 & 1,7 \\
\hline 7 & Conceptual subitizing with place value and skip counting & $1,6,7$ \\
\hline 8 & Conceptual subitizing with place value and multiplication & 6,7 \\
\hline Age & Developmental progression for verbal and object counting & Games \\
\hline $0-1$ & $\begin{array}{l}\text { Pre-counter } \\
\text { Chanter }\end{array}$ & - \\
\hline $1-2$ & Reciter & - \\
\hline 3 & Reciter (10) & - \\
\hline 3 & Corresponder & $2,3,4,6,7,12$ \\
\hline 4 & Counter (small numbers) & $2,3,4,6,7,9,11$ \\
\hline 4 & Counter (10) & $1,2,3,4$ \\
\hline 4 & Producer (small numbers) & 7 \\
\hline 5 & Counter \& producer $(10+)$ & 1,7 \\
\hline 5 & Counter backward from 10 & - \\
\hline 6 & Counter form $\mathrm{N}(\mathrm{N}+1, \mathrm{~N}-1)$ & 5,8 \\
\hline 6 & Skip counter by 10 s to 100 & $5,6,7,8,13$ \\
\hline 6 & Counter to 100 & 13 \\
\hline 6 & Counter on using patterns & 7 \\
\hline 6 & Skip counter & $5,8,13$ \\
\hline 6 & Counter of imagined items & - \\
\hline 6 & Counter on keeping track & - \\
\hline 6 & Counter of quantitative units/Place value & 6,7 \\
\hline 6 & Counter to 200 & - \\
\hline 7 & Number conserver & - \\
\hline 7 & Counter forward and back & - \\
\hline Age & $\begin{array}{l}\text { Developmental progression for comparing, ordering, and } \\
\text { estimating numbers }\end{array}$ & Games \\
\hline $0-1$ & Many-to-one corresponder & - \\
\hline $1-2$ & One-to-one corresponder & - \\
\hline $1-2$ & Object corresponder & - \\
\hline $1-2$ & Perceptual comparer & $3,9,11$ \\
\hline 3 & First-second ordinal counter & - \\
\hline 3 & Nonverbal comparer of similar items (one-four items) & 9,11 \\
\hline 4 & Nonverbal comparer of dissimilar items & - \\
\hline 4 & Matching comparer & - \\
\hline 4 & Counting comparer (same size) & $3,4,9,11$ \\
\hline 4 & Mental number line to five & - \\
\hline 5 & Counting comparer (five) & 3 \\
\hline 5 & Ordinal counter & 8,12 \\
\hline 5 & Spatial extent estimator-small & - \\
\hline 5 & Counting comparer (10) & 3 \\
\hline 6 & Mental number line to 10 & - \\
\hline 6 & Serial orderer to $6+$ & - \\
\hline
\end{tabular}




\begin{tabular}{llc}
6 & Spatial Extent Estimator & - \\
7 & Place Value Comparer & - \\
7 & Mental Number Line to 100 & - \\
7 & Scanning with Intuitive Quantification Estimator & - \\
8 & Mental number line to 1000 & 10 \\
8 & Benchmarks Estimator & - \\
8 & Composition Estimator & - \\
\hline
\end{tabular}

It is seen that the games mostly support the trajectories of the "recognition of number and subitizing" and "verbal and object counting" for the children aged between 4 and 6 . For the trajectory of the "comparing, ordering and estimating numbers" there are games supporting the perceptual and counting comparison and ordinal numbers. There is only one game supporting the estimation skills. It is important to include more games that support the skills about the relative size of the number, its position and their proximity to other numbers to improve this learning trajectory.

Perceptual and conceptual subitizing are ultimately significant for the "recognition of number and subitizing". Children build their knowledge of counting and cardinality at an early age on perceptual subitizing. Perceptual subitizing requires a small number of multiplicities ( 4 or 5 ) to be determined quickly and accurately without counting using mathematical operations (Clements, 1999), and conceptual subitizing requires dividing the number of large objects into small groups (Geary, 2003). Seven games out of 13 games support perceptual subitizing skills. However, both educators and families may need to provide some guidance to children to support this skill. For instance, in the first game named Counting Fish children should be directed to tell the number of fish at the stages covering 4-5 fish. One of the basic features of subitizing is to show and close objects to the child for a short time. Thus, perceptual and conceptual subitizing is performed without mathematical operation to determine the number of objects in the group. This game does not contain this feature. However, the user can turn off the display after the child is able to see the screen image quickly under the guidance of the user. At the stages where more fish are asked, children can be guided to recognize the number in groups more quickly and practically. In the third game named Fuzz BugsCounting, Sorting, \& Comparing the number of Fuzz Bugs stacked in jars is asked to the children. The conceptual subitizing skill can be used in the early stages of development so that the child can see that grouping will faciliate the working with a large numbers. In the game named Monster Mansion-Number Match (the fourth game) children hear the number of dots when they open the windows. It may improve their counting skills. However, after playing the game in this manner for a while the child can be directed to decide about what the number is. Thus, by developing their own counting strategies, they can determine the same number of objects through the conceptual subitizing.

The games reviewed generally support the trajectory of "verbal and object counting" for children aged 3-6. The games mostly support one-to-one correspondence, determining the number of objects, counting and skip counting. The point here is that the games for counting and quantifying show parallelism with the games supporting the subitizing phase. Subitizing is seen as a prerequisite for counting and as a complementary skill for the development of counting (Butterworth, 1999). The 
subitizing skills of the examined games have been revealed, but it is also stated that some instructions should be given to the child to play a supporting role for this skill. In the Common Core Standards section of the ABCya activities the standards set for the youngest age group start with the "counting \& cardinality" stage. Therefore, it can be argued that there is no direct goal to support the subitizing in games. In the findings section, the correlations between games and learning trajectories were uncovered, and it also included some suggestions about what kind of guidance should be given to the child in order to provide the features to support the subitizing skill. The games numbered 3, 4, 6, 7, 9 and 11 support both subitizing and counting skills. However, in order to improve the subitizing skills games should have certain features, for instance, the objects should be given on the screen for a short period, all the objects in the group should be displayed at the same time, and the grouping should support the concept of counting through conceptual subitizing. Some of the games have these features. Therefore, they can be used to support subitizing under the supercision of an educator. Following the game, children should be allowed to play with features that improve their counting skills, and children should benefit from their contribution to the development of counting principles.

The number of games supporting the trajectory of "Comparing, ordering, and estimating numbers" is much more limited. The games reviewed mostly support the perceptual comparison, comparing the number of objects of groups using identical objects and the ordinal value principle. The game named How Many Marbles deals with the development of the estimation skills. In the game children are asked to make estimations about the number of objects in a group. In this learning trajectory, the development of children in terms of their relative size, proximity to other numbers, and their position is paid importance. This skill is one of the basic characteristics of number sense and supports children to understand the relationships between numbers. A number line is included in the Base Ten Fun game. However, this number line is somewhat different from the use of the mental number line. In the mental number line, the starting and ending points of the number line must be determined, and the number magnitudes must be estimated without specifying the numbers in the range. Therefore, adding or integrating such a component to the games can improve the estimation skills of children.

\section{Discussion and Conclusion}

Research suggests that both virtual manipulatives and digital games positively support the development of children's mathematical skills (Manginas \& Nikolantonakis, 2018; Miller, 2018; Moyer-Packenham et al., 2015; Pope \& Mangram, 2015; Rogowsky et al., 2017). However, teachers reported that they have no sufficient information about which games or manipulatives can support which mathematical skills in the teaching process (Kirriemuir \& McFarlane, 2004; Koh, Kin, Wadhwa, \& Lim, 2012), that they have limited time to explore these games and associate them with the teaching process (Kirriemuir \& McFarlane, 2004), and that they have problems in finding appropriate games in terms of visual, contextual, and educational features of children (Baek, 2008). In addition, the most important obstacle in this regard is the inadequacy of the relationship between knowledge and skills in the game and educational arrangements (McFarlane, Sparrowhawk, \& Heald, 2002). Without adequate information on the content of the game, its relationship with educational standards and its effectiveness in 
the implementation process, teachers cannot obtain sufficient evidence of the necessity and importance of the use of these games in their classrooms (Wale, 2013). It can be argued that providing digital mathematical games that can help teachers in relation to the development levels of children will facilitate teachers' work. The educational activity set called ABCya was developed by two teachers who wanted to use digital games in their classrooms but faced some limitations both in terms of materials and in terms of the quality of the games. Teachers designed educational games using their competencies in programming and graphic design and started to use these games in their classrooms. As they observed that other teachers also used the games in their lessons and that these games had positive effects on the students, they continued to produce more educational games and put forward such an activity set. Associating the games in this practice, which arises from the needs of teachers and students, with the Common Core Standards, will facilitate the transfer of the games to the instructional process. However, the Common Core Standards include instructional objectives created by bringing together administrators and educators in states in the United States. Therefore, it is important to link games with progressive mathematical learning trajectories rather than country-specific curricula or achievements. Through such an association, teachers, families and researchers in different countries will be able to see the stages of a child's number development through their learning trajectories (Sarama \& Clements, 2009a) and also, will have information about which games are useful in supporting these stages.

The aim stage of the learning trajectories tries to define the mathematical content that teachers are expected to bring to children. Developmental progression provides teachers with a tool for recognizing children's level of mathematical development and a higher level. Educational activities paired with developmental progression provide guidance on the type of activity that will support student learning and help to explain why the identified activities can be effective. Several components of the trajectories answers different questions, for instance, "the goal" component answers the question "where do you want to go?"; "the developmental progression" component answers the question "Where are you now?" and the "instructional activities" component answers the question "how can you reach your next goal?" (Clements \& Sarama, 2014). Researcher argued that there would be no standard of instructional activities and that they could be diversified with the support of teachers, families and sociocultural environment depending on the developmental process. In this context, digital games are seen as important tools in structuring and diversifying instructional activities. Research emphasizes the effectiveness of computer-assisted instructional manipulatives, moving away from the traditional idea that children in particular can learn better with concrete materials (Clements, 2002; Sarama \& Clements, 2016). Therefore, demonstrating the learning trajectory characteristics of the games can guide teachers and families about the instructional activities that will bring children to a higher level goal from their current level.

Gelman and Gallistel (1978) stated that in order to make meaningful counting, children should acquire some counting principles. The one-to-one principle is that each object is represented by a number word while counting a group of objects. The stableorder-principle states that there is a fixed order of number words in the counting, while the cardinal principle states that the last said number represents the sum of the plurality of objects in counting. The abstraction principle states that it is not important in 
counting whether objects that can be counted in a group are associated or not. The order-irrelevance principle states that when we count an object plurality, it is not important to determine the number of object plurality from which object we start and which object we continue by counting. The games examined in the findings section support both the learning trajectories and these five counting principles.

Especially in countries where the curriculum is more strict and education system is more exam-oriented, teachers may feel themselves under pressure to complete the curriculum within the specified time. Even games with clear educational components can cause teachers to come across some problems that require time (Baek, 2008; Watson, Yang, \& Ruggiero, 2012). For example, many variables can lead to time consuming activities, such as the loading time of the game, the introduction stages of the game, the learning of the children and teachers, and the involvement of children outside of the educational dimension of the game (Rutter \& Bryce, 2006). In order to avoid this, the introduction of educational digital games, their content and which mathematical skills children will support can facilitate teachers to save time and encourage the use of digital games.

In the context of the use of digital games math class, teachers in Turkey reported that although they believe in the positive impact of the game they also experience some difficulties about finding educational games in native language, inaccessibility of some game software, worrying about program association, time limitation and limiting computer proficiency of teachers and students (Demirbilek \& Tamer, 2010). Finding a digital math game written in Turkish is a serious problem. Therefore, it is argued that there is a need for digital math games with educational background designed in accordance with Turkish background. However, within the scope of the FATIH project, which was initiated in 2012, both pilot studies and the project implementations provided in hardware and software infrastructure in Turkish schools which included educational e-content, directing teachers to use interactive whiteboards and tablet computers and inservice training activities for teachers. In this context, it is thought that the potential difficulties that Turkish teachers may experience will be about introducing and using digital game platforms (in terms of which educational applications and which games can be used, which gains support etc.) beyond the introduction of digital platforms to the classroom environment. There are some experimental studies which use digital games to support children's counting skills and number sense (Manginas \& Nikolantonakis, 2018; Pope \& Mangram, 2015). In addition to the studies cited above this study contributes to the field in terms of making teachers much more aware of the educational games included in the ABCya activities. In addition, it is very important that the mathematical development of children should be supported by families in informal learning environments, especially from early childhood. For this reason, it is very important to introduce the digital platforms that include educational game activities to both teachers and families and to inform them about their contribution to academic development of the children. 


\section{References}

Baek, Y. K. (2008). What hinders teachers in using computer and video games in the classroom? Exploring factors inhibiting the uptake of computer and video games. Cyber Psychology and Behavior, 6, 665-671.

Bozkurt, A. (2014). Homo Ludens: Dijital oyunlar ve eğitim. Ĕgitim Teknolojileri Araştırmaları Dergisi, 5(1), 1-21.

Böke, K. (2009). Sosyal bilimlerde araştırma yöntemleri. İstanbul: Alfa.

Butterworth, B. (1999). The mathematical brain. London: Macmillan.

Clements, D. H. (1999). "Concrete' manipulatives, concrete ideas. Contemporary Issues in Early Childhood, 1, 45-60.

Clements, D. H. (2002). Computers in early childhood mathematics. Contemporary Issues in Early Childhood, 3(2), 160-181.

Clements, D. H., \& Sarama, J. (2007). Effects of a preschool mathematics curriculum: Summative research on the Building Blocks project. Journal for Research in Mathematics Education, 38, 136-163.

Clements, D. H., \& Sarama, J. (2014). Developing young children's mathematical thinking and understanding. In S. Robson \& S. F. Quinn (Eds.), The Routledge international handbook of young children's thinking and understanding (pp. 331344). Routledge: New York.

Demirbilek, M., \& Tamer, S. L. (2010). Math teachers' perspectives on using educational computer games in math education. Procedia Social and Behavioral Sciences, 9, 709-716.

Downe-Wambolt, B. (1992). Content analysis: method, applications and issues. Health Care for Women International, 13, 313-321.

Geary, D. C. (2003). Arithmetical development: Commentary and future directions. In A. Baroody \& A. Dowker (Eds.), The development of arithmetic concepts and skills: Constructing adaptive expertise (pp. 453-464). Mahwah, NJ: Erlbaum.

Gelman, R., \& Gallistel, C. R. (1978). The child's understanding of number. Cambridge, MA: Harvard University Press.

Jovanova-Mitkovska, S. (2018). Computer games and the development of mathematical concepts. Paper at the VI. International Scientific Conference, Slovenia, 2-4 July, pp. 133-138.

Kirriemuir, J., \& McFarlane, A. (2004). Literature Review in Games and Learning, A NESTA Futurelab Research report - report 8. 2004. Available at: https://telearn.archivesouvertes.fr/hal-00190453/file/kirriemuir-j-2004-r8.pdf.

Koh, E., Kin, Y. G., Wadhwa, B., \& Lim, J. (2012). Teacher perception of games in Singapore Schools. Simulation \& Gaming, 43(1), 51-66.

MacDonald, B. L., \& Shumway, J. F. (2016). Subitizing games: Assessing preschool children's number understanding. Teaching Children Mathematics, 22(6), 340-348.

MacDonald, B. L., \& Wilkins, J. L. M. (2016). Seven types of subitizing activity characterizing young children's mental activity. In S. Marx (Ed.), Qualitative research in STEM (pp. 256-286). New York, NY: Routledge.

Manginas, G., \& Nikolantonakis, C. (2018). The contribution of mathematics online games to qualitive differentiation and intrinsic motivation of students with mild intellectual disabilities. European Journal of Special Education Research, 3(1), 5881. 
McFarlane, A., Sparrowhawk, A., \& Heald, Y. (2002). Report on the educational use of games. TEEM (Teachers evaluating educational multimedia), Cambridge.

Miller, T. (2018). Developing numeracy skills using interactive technology in a playbased learning environment. International Journal of STEM Education, 5(39), 2-11.

Moyer, P. S., Bolyard, J. J., \& Spikell, M. A. (2002). What are virtual manipulatives? Teaching Children Mathematics, 8(6), 372-377.

Moyer-Packenham, P. S., Shumway, J. F., Bullock, E., Tucker, S. I., Anderson-Pence, K. L., Westenskow, A., ... Jordan, K. (2015). Young children's learning performance and efficiency when using virtual manipulative mathematics iPad apps. Journal of Computers in Mathematics and Science Teaching, 34(1), 41-69.

National Council of Teachers of Mathematics [NCTM]. (2000). Principles and standards for school mathematics. Reston, Va. NCTM.

Oblinger, D. (2004). The next generation of educational engagement. Journal of Interactive Media in Education, 8, 1-18.

Ortiz, E. (2017). Pre-service teachers' ability to identify and implement cognitive levels in mathematics learning. Issues in the Undergraduate Mathematics Preparation of School Teachers, 3, 1-14.

Pope, H., \& Mangram, C. (2015). Wuzzit Trouble: The influence of a digital math game on student number sense. International Journal of Serious Games, 2(4), 5-21.

Rogowsky, B. A., Terwilliger, C. C., Young, C. A., \& Kribbs, E. E. (2017). Playful learning with technology: the effect of computer-assisted instruction on literacy and numeracy skills of pre-schoolers. International Journal of Play, 7(1), 60-80. https://doi.org/10.1080/21594937.2017.1348324.

Rutter, J., \& Bryce, J. (2006). Understanding digital games. London: Sage Publications.

Samur, Y. (2012). Measuring engagement effects of educational games and virtual manipulatives on mathematics (Unpublished Doctor of Philosophy Dissertation). Virginia Polytechnic Institute and State University, Virginia, USA.

Sarama, J., \& Clements, D. H. (2009a). Early childhood mathematics education research: Learning trajectories for young children. New York: Routledge.

Sarama, J., \& Clements, D. H. (2009b). Teaching math in the primary grades: The learning trajectories approach. National Association for the Education of Young Children, 64(2), 63-65.

Sarama, J., \& Clements, D. H. (2016). Physical and virtual manipulatives: What is "concrete"? In P. S. Moyer-Packenham (Ed.), International perspectives on teaching and learning mathematics with virtual manipulatives (Vol. 3, pp. 71-93). Switzerland: Springer International Publishing.

Siegler, R. S., \& Booth, J. L. (2004). Development of numerical estimation in young children. Child Development, 75, 428 - 444.

Simon, M. A. (1995). Reconstructing mathematics pedagogy from a constructivist perspective. Journal for Research in Mathematics Education, 26(2), 114-145.

Wale, C. M. (2013). Evaluation of the effect of a digital mathematics game on academic achievement (Published Doctor of Philosophy Dissertation). University of Northern Colorado, Greeley.

Watson, W. R., Yang, S., \& Ruggiero, D. (2012). Games in schools: teachers' perceptions of barriers to game-based learning. Paper at the AECT International Convention, Louisville, October 30-November 3, pp. 229-238. 
Wilson, P. H., Mojica, G. F., \& Confrey, J. (2013). Learning trajectories in teacher education: Supporting teachers' understandings of students' mathematical thinking. The Journal of Mathematical Behavior, 32(2), 103-121. 